ROSA, Alexandre Morais da; BISPO, Andrea Ferreira. Prostituição: o impasse entre o Legalismo Moral e o Princípio do Dano. Revista Eletrônica Direito e Política, Programa de Pós-Graduação Stricto Sensu em Ciência Jurídica da UNIVALI, Itajaí, v.12, n.3, $3^{\circ}$ quadrimestre de 2017. Disponível em: www.univali.br/direitoepolitica - ISSN 1980-7791

\title{
PROSTITUIÇÃO: O IMPASSE ENTRE O LEGALISMO MORAL E O PRINCÍPIO DO DANO
}

\author{
PROSTITUTION: THE IMPASSE BETWEEN MORAL LEGALISM AND THE
}

PRINCIPLE OF DAMAGE

Alexandre Morais da Rosa'

Andrea Ferreira Bispo²

SUMÁRIO: Introdução; 1 Um breve retrospecto da prostituição no Brasil; 2 Breve histórico da criminalização da prostituição no Brasil; 3 A intervenção do estado na vida privada, segundo John Stuart Mill; 4 Como são explicados os interditos opostos à prostituição; 5 Direitos invioláveis como parâmetro para os processos de criminalização primária e secundária; Considerações finais; Referência das fontes citadas.

\section{RESUMO}

O presente artigo tem por objetivo expor os fundamentos da intervenção do Estado brasileiro na liberdade individual por meio da criminalização indireta da prostituição. O método adotado será a revisão bibliográfica, tendo por marco teórico a obra Sobre a Liberdade, de John Stuart Mill. Inicialmente será feito um breve histórico da prostituição e dos processos de criminalização dessa atividade no Brasil. Em seguida será apresentado o princípio do dano, segundo o qual o único fim pelo qual a humanidade está autorizada, individual ou coletivamente, a interferir na liberdade de ação de qualquer um de seus integrantes é a autodefesa. Será destacado que um dos fundamentos da República Federativa do Brasil é a dignidade da pessoa humana, de modo que a liberdade individual não pode ser limitada pelo legalismo moral. Assim, somente podem ser criminalizadas condutas que ofendam direitos constitucionalmente considerados invioláveis. Por fim, se irá propor a inconstitucionalidade dos crimes contra a dignidade sexual, quando os prestadores de serviços são sujeitos que optaram livremente por

\footnotetext{
${ }^{1}$ Doutor em Direito (UFPR). Professor dos Programas de Pós-Graduação em Direito, da UFSC e da UNIVALI. Juiz de Direito (TJSC). Pesquisador do CNPQ.

2 Mestranda do Programa de Pós-Graduação em Direito, na linha de pesquisa Intervenção Penal, Segurança Pública e Direitos Humanos, da Universidade Federal do Estado do Pará.
} 
ROSA, Alexandre Morais da; BISPO, Andrea Ferreira. Prostituição: o impasse entre o Legalismo Moral e o Princípio do Dano. Revista Eletrônica Direito e Política, Programa de Pós-Graduação Stricto Sensu em Ciência Jurídica da UNIVALI, Itajaí, v.12, n.3, $3^{\circ}$ quadrimestre de 2017. Disponível em: www.univali.br/direitoepolitica - ISSN 1980-7791

essa profissão, e que inexistência de regulamentação da profissão implica em tratar de modo desigual uma categoria de trabalhadores, o que gera exclusão social atentatória à dignidade da pessoa humana.

PALAVRAS-CHAVE: Prostituição; Princípio do Dano; Legalismo moral; Inexistência de Regulamentação; Exclusão social

\section{ABSTRACT}

The purpose of this article is to expose the foundations of the intervention of the Brazilian State in the individual freedom through the indirect criminalization of prostitution. The method adopted will be the bibliographical revision, having by theoretical mark the work on the Freedom, of John Stuart Mill. Initially a brief history of prostitution and the processes of criminalization of this activity in Brazil will be made. Then the principle of harm will be presented, according to which the only purpose for which humanity is authorized, individually or collectively, to interfere with the freedom of action of any of its members is self-defense. It will be emphasized that one of the foundations of the Federative Republic of Brazil is the dignity of the human person, so that individual freedom can not be limited by moral legalism. Thus, only conduct that offends rights constitutionally considered inviolable can be criminalized. Finally, it will be proposed that crimes against sexual dignity are unconstitutional, when service providers are subjects who have freely chosen this profession, and that the lack of regulation of the profession implies treating unequally a category of workers, which generates social exclusion that threatens the dignity of the human person.

KEYWORDS: Prostitution. Principle of Damage. Moral legalism. Inexistence of Regulation. Social exclusion.

\section{INTRODUÇÃO}

Na introdução do Malleus Maleficarum, O Martelo das Feiticeiras, Rosie Marie Muraro $^{3}$, apresenta uma visão da história da mulher e indica o momento em que o processo de dominação do feminino teve início.

Segundo ela, a supremacia masculina iniciou-se nas sociedades de caça aos grandes animais, mas foi somente no decorrer do neolítico que o homem passou a dominar a sua função biológica reprodutora e se tornou capaz de controlá-la, surgindo o matrimônio sidiasmático, baseado na monogamia

\footnotetext{
3 KRAMER, Heinrich; SPRENGER, James. Malleus Maleficarum: O Martelo das Feiticeiras. Trad.
} Paulo Froes. Rio de Janeiro: Best Bolso, 2015, pp. 9-12. 
ROSA, Alexandre Morais da; BISPO, Andrea Ferreira. Prostituição: o impasse entre o Legalismo Moral e o Princípio do Dano. Revista Eletrônica Direito e Política, Programa de Pós-Graduação Stricto Sensu em Ciência Jurídica da UNIVALI, Itajaí, v.12, n.3, $3^{\circ}$ quadrimestre de 2017. Disponível em: www.univali.br/direitoepolitica - ISSN 1980-7791

feminina, porém facilmente dissolvível por qualquer das partes.

A esse introito, Friedrich Engels ${ }^{4}$ acrescenta que a razão pela qual o matrimônio sidiasmático se converteu em uma monogamia estável foi a entrada em jogo de uma nova força impulsionadora da ordem social: a propriedade privada. Para ele, a domesticação de animais e a criação de gado criaram uma espécie de riqueza que precisava apenas de vigilância e dos cuidados mais primitivos para reproduzir-se em proporção cada vez maior e fornecer abundantíssima alimentação de carne e leite, relegando ao segundo plano todos os meios de produção anteriormente utilizados. Convertidas todas essas riquezas em propriedade particular das famílias, superou-se o modelo de transmissão da herança por linha materna, adotando-se, no lugar dele, a filiação masculina e o direito hereditário paterno.

Nesse novo formato conjugal, o homem se apoderou da direção do lar e a mulher foi convertida em simples instrumento de reprodução: o marido tinha o dever de sustentar a casa e de procriar filhos; da esposa era exigida castidade e a capacidade de cuidar da família a fim de conferir ao esposo o status social de adulto; e dos filhos requeria-se que a paternidade fosse indiscutível, requisito necessário para que apenas os descendentes biológicos, na qualidade de herdeiros diretos, entrassem na posse da herança.

Portanto, a monogamia não surgiu do amor sexual individual, com o qual, aliás, pouco tem em comum, mas sim da necessidade econômica de consolidar a transmissão hereditária da propriedade privada.

A partir do estabelecimento dessa prioridade pelo patriarcado, foram impostas às mulheres uma série de restrições quanto ao exercício do direito à propriedade e à sucessão, ao acesso à educação formal igualitária e à profissões que favoreciam sua autonomia financeira e a elevação do seu status social.

Em um ambiente francamente hostil, desde criança elas passavam a ser

\footnotetext{
${ }^{4}$ ENGELS, Friedrich. A origem da família, da propriedade privada e do Estado. Trad. Leandro Konder. 9a ed. Rio de Janeiro: Civilização Brasileira, 1984, pp. 57-59.
} 
ROSA, Alexandre Morais da; BISPO, Andrea Ferreira. Prostituição: o impasse entre o Legalismo Moral e o Princípio do Dano. Revista Eletrônica Direito e Política, Programa de Pós-Graduação Stricto Sensu em Ciência Jurídica da UNIVALI, Itajaí, v.12, n.3, $3^{\circ}$ quadrimestre de 2017. Disponível em: www.univali.br/direitoepolitica - ISSN 1980-7791

instruídas para se adequarem ao modelo de mulher apropriada ao casamento: alguém cujo corpo deveria ter a passividade dos objetos e cujo espírito deveria ser cordato e abnegado, abjurador da carne e do prazer, beato e submisso à cangalha.

Em contrapartida, os modelos opostos ao perfil de uma mulher ideal formavam as classes das estigmatizadas, sendo uma dessas classes a das prostitutas.

No Brasil, em que pese a luta e a trajetória das mulheres tê-las levado a um progressivo ingresso nos espaços onde as decisões políticas são tomadas, com importantes e significativas pautas alcançadas, verifica-se que o estigma contra a prostituta não esmaeceu e sua condição social continua sendo marginalizada, uma vez que da falta de regulamentação - concomitante à criminalização das prestações de serviços envolventes a essa profissão - decorrem a impossibilidade de que Ihes sejam asseguradas garantias previdenciárias e trabalhistas.

Dessa maneira, mesmo que não haja uma lei que proíba a prestação de serviços sexuais por dinheiro, as pessoas que os prestam são associadas, numa relação de "contágio", a crimes como lenocínio, tráfico de drogas e humano, dentre muitos outros, o que legitima a atuação das agências formais de controle social a empreenderem contra elas ações discriminatórias e atentatórias aos direitos humanos, tais como as conduções coercitivas realizadas pela Polícia Federal no Estado de Roraima no dia 04 de maio de $2017^{5}$.

O objetivo deste artigo é analisar o que justifica a criminalização indireta da prostituição no Brasil, enfatizando que esse tema está intrinsecamente relacionado com a história das mulheres, razão pela qual o exame se limitará à análise da prostituição feminina exercida por pessoas absolutamente capazes.

A partir de revisão bibliográfica, cujo marco teórico é a obra Sobre a Liberdade, de John Stuart Mill, será proposta uma hipótese de interpretação

\footnotetext{
5 FOLHA DE BOA VISTA. PF deflagra operação em zona de prostituição da Capital e do Interior. Disponível em: http://www.folhabv.com.br/noticia/-PF-deflagra-operacao-em-zona-deprostituicao-da-Capital-e-do-Interior/28056. Acesso em 04 jul 2017.
} 
ROSA, Alexandre Morais da; BISPO, Andrea Ferreira. Prostituição: o impasse entre o Legalismo Moral e o Princípio do Dano. Revista Eletrônica Direito e Política, Programa de Pós-Graduação Stricto Sensu em Ciência Jurídica da UNIVALI, Itajaí, v.12, n.3, $3^{\circ}$ quadrimestre de 2017. Disponível em: www.univali.br/direitoepolitica - ISSN 1980-7791

dessas normas proibitivas, destacando-se o que dispõe a Constituição brasileira sobre a proteção aos direitos fundamentais.

\section{UM BREVE RETROSPECTO DA PROSTITUIÇÃO NO BRASIL}

À medida que o domínio patriarcal consolidou seu poder de decidir sobre a vida das mulheres, a visão sobre a prostituta teve diferentes referenciais.

Regina Navarro Lins ${ }^{6}$ afirma que o sexo com mulheres que não se casavam nem sempre foi desprezado. Na Antiguidade, as sacerdotisas que se dedicavam a essa prática eram tratadas com respeito pela sociedade. Porém, com a ascensão do monoteísmo cristão, e o consequente fim das atividades templárias, as mulheres que antes se dedicavam a elas passaram a prestar serviços sexuais com o objetivo de obterem renda.

Na Idade Média, a visão sobre a prostituição era ambígua. Aqui, as preleções sobre o pecado da luxúria, retratadas no convite de Santo Agostinho para que se "expulsem as cortesãs, porque senão logo as paixões tumultuarão tudo (...elas) levam uma vida totalmente impura, mas as leis da ordem Ihes atribuem um lugar, por mais vil que seja"7, foram trespassadas pela noção de tolerância de Tomás de Aquino, para quem "toda criatura é necessariamente imperfeita, quando comparada à perfeição divina"8.

A literatura produzida nessa época atribuía às mulheres a culpa pelo pecado da luxúria, introduzindo a ideia de que para os homens a fornicação podia até ser desculpável, desde que não fosse demasiado frequente e cometida por solteiros com mulheres realmente livres de vínculo.

A partir dessa perspectiva enaltecedora do mito da incontinência masculina,

${ }^{6}$ LINS, Regina Navarro. A cama na varanda: arejando nossas ideias a respeito de amor e sexo: novas tendências. Rio de Janeiro: BestSeller, 2007, pp. 201-206.

7 ROSSIAUD, Jacques. A Prostituição na Idade Média. Trad. Cláudia Schilling. Rio de Janeiro: Paz e Terra, 1991, p. 78.

8 BOEHNER, Philotheus. GILSON, Etienne. História da filosofia cristã: desde as origens até Nicolau de Cusa. Trad. Raimundo Vier. 13. Ed. Petrópolis: Vozes, 2012, p. 466. 
ROSA, Alexandre Morais da; BISPO, Andrea Ferreira. Prostituição: o impasse entre o Legalismo Moral e o Princípio do Dano. Revista Eletrônica Direito e Política, Programa de Pós-Graduação Stricto Sensu em Ciência Jurídica da UNIVALI, Itajaí, v.12, n.3, $3^{\circ}$ quadrimestre de 2017. Disponível em: www.univali.br/direitoepolitica - ISSN 1980-7791

avançou-se, do século XIII em diante, com uma diretriz política sobre a prostituição que é usada ainda hoje para, ao mesmo tempo, justificar a "tolerância" para com a atividade e envolvê-la em preconceito. No senso comum, alerta Rossiaud, invocava-se a máxima de Tomás de Aquino, para quem "a mulher pública é na sociedade o que a sentina é no mar e os esgotos no palácio. Tampem esses esgotos e todo palácio ficará contaminado" 9 .

O percurso histórico da prostituição no Brasil não escapou a essa lógica.

De pessoas consideradas pelo jesuíta Manoel da Nóbrega ${ }^{10}$ como elemento indispensável para o êxito do projeto português de colonização; às mulheres que buscavam trabalho nos primeiros e incipientes lupanares da São Paulo do século XVIII e eram alvo do projeto salvacionista da Igreja Católica, que pretendia recuperá-las pelo casamento ${ }^{11}$; às zonas de meretrício de meados do século XIX e início do século $X X$, construídas e frequentadas em todo Brasil por homens de variadas classes sociais; à absorção da presença de prostitutas estrangeiras, símbolo de modernidade e requinte em uma Rio de Janeiro que ia sendo planejada por Alfred Agache ${ }^{12}$, sem considerar os aspectos culturais multifacetários da metrópole, que descartava as prostitutas do baixo clero, por não se ajustarem à sua utopia urbanística ${ }^{13}$; ao quadrilátero do amor, região do Bairro da Campina, em Belém do Pará, onde foram construídos, em 1921, os luxuosos cabarés fechados na década de 1970 por uma ditadura militar incomodada com a presença das mulheres que, na Travessa Riachuelo, subvertiam a hierarquia de valor fundada na família, na contenção e disciplina

9 ROSSIAUD, Jacques. A Prostituição na Idade Média. Trad. Cláudia Schilling. Rio de Janeiro: Paz e Terra, 1991, p. 79.

10 NÓBREGA, Manoel da. Cartas do Brasil 1549-1560. Rio de Janeiro: Publicações da Academia Brasileira, 1931, pp. 79-80.

11 FONSECA, Guido. A História da Prostituição em São Paulo. São Paulo: Editora Resenha Universitária, 1982, p. 52.

12 RAGO, Margareth. Do cabaré ao lar: a utopia da cidade disciplinar: Brasil: 1890-1930. Rio de Janeiro: Paz e Terra, 1985, p. 43.

${ }^{13}$ CARMO, Paulo Sérgio do. Entre a Luxúria e o Pudor: a história do sexo no Brasil. São Paulo: Octávio, 2001, p. 176. 
ROSA, Alexandre Morais da; BISPO, Andrea Ferreira. Prostituição: o impasse entre o Legalismo Moral e o Princípio do Dano. Revista Eletrônica Direito e Política, Programa de Pós-Graduação Stricto Sensu em Ciência Jurídica da UNIVALI, Itajaí, v.12, n.3, $3^{\circ}$ quadrimestre de 2017. Disponível em: www.univali.br/direitoepolitica - ISSN 1980-7791

dos desejos defendida pelo puritano governador Alacid Nunes ${ }^{14}$; à Zona do Mangue carioca, convertida na Vila Mimosa, em 1982 local de trabalho de Gabriela Leite ${ }^{15}$ e de 2000 a 2002 espaço onde a excelente Soraya Simões realizou sua pesquisa de campo, o que se tem como imutável é o sistemático desrespeito aos Direitos Fundamentais das mulheres.

Lena Menezes ${ }^{16}$ acentua que no princípio do século $\mathrm{XX}$, a modernidade reclamava a eliminação do atraso colonial, dos costumes e usos tradicionais e a construção de uma nova imagem urbana, livre das ruelas estreitas e sujas e do contingente de indesejáveis que infestava o centro das cidades.

É nesse período, conforme lembra Soihet, que os discursos médicos, influenciados pelos paradigmas etiológicos de Lombroso e Ferrero - que definiam as prostitutas como portadoras de "um defeito atávico, imanente à própria natureza de certas criaturas, que as levava, inevitavelmente, à infringência da lei penal" 17 - forneceram a fundamentação teórico-acadêmica para legitimar a exclusão das prostitutas em uma sociedade que se pautava pelos padrões europeus de civilidade e pretendia que os assuntos fossem discutidos a partir da racionalidade positivista.

Simões anota que, para os agentes do planejamento oficial, havia a compreensão de que seria praticamente impossível extinguir a prostituição, pois se tratava de um fenômeno ao mesmo tempo social e natural. Por isso, a política de tolerância se estruturou em duas premissas: a existência de locais específicos para o exercício da prostituição e o controle de saúde das prostitutas, medidas que "preservariam os valores morais definidos por uma lógica burguesa,

${ }^{14}$ BARRETO, Maria de Lourdes Araújo. Todos calam, nós falamos. Comitê Latino Americano e do Caribe para a Defesa dos Direitos da Mulher (CLADEM). Mulheres: vigiadas e castigadas. São Paulo: Cladem-Brasil, 1995, pp. 447-461

15 LEITE, Gabriela. Filha, Mãe, avó e puta. Rio de Janeiro: Objetiva, 2009.

16 MENEZES, Lena Medeiro de. Estrangeiros e o Comércio do Prazer nas Ruas do Rio - 1890 à 1930. Rio de Janeiro: Arquivo Nacional, 1992, p. 117.

17 SOIHET, Rachel. Condição Feminina e Formas de Violência: mulheres pobres e ordem urbana 1890-1920. Rio de Janeiro: Forense Universitária, 1989, p. 82. 
ROSA, Alexandre Morais da; BISPO, Andrea Ferreira. Prostituição: o impasse entre o Legalismo Moral e o Princípio do Dano. Revista Eletrônica Direito e Política, Programa de Pós-Graduação Stricto Sensu em Ciência Jurídica da UNIVALI, Itajaí, v.12, n.3, $3^{\circ}$ quadrimestre de 2017. Disponível em: www.univali.br/direitoepolitica - ISSN 1980-7791

delineando o perfil da prostituta de maneira a enquadrá-la como desprovida de qualquer faculdade de discernimento" ${ }^{18}$.

Edson Holtz ${ }^{19}$ destaca que a crítica higienista à prostituta, implicou, ainda, na sua responsabilização pela degradação física e moral do homem e, por extensão, da família e da sociedade, teoria que, associada à campanha que atribuía a elas a responsabilidade pela transmissão da sífilis e à defesa da moralização das relações sexuais, obteve ampla aprovação pública, tornando-se possível, como recorda Beatriz Kushnir ${ }^{20}$, que as prostitutas fossem confinadas na periferia dos direitos humanos, processo que vai se reproduzindo e se avolumando na medida em que o liberalismo econômico, com sua política predatória, maximiza a insegurança social.

Atualmente, apesar das falas das mulheres que têm na prostituição seu trabalho e militância serem suficientemente esclarecedoras, persiste como que uma névoa encobrindo essa realidade de trabalho.

Como recorda Margareth Rago ${ }^{21}$, a forma como se dão as relações profissionais no chamado baixo meretrício continua cercada de mistérios, fantasias e objeções, incitando a imaginação a reconhecer a existência de mulheres de segunda e de terceira ordens, ratificando as descrições das teses positivistas defendidas desde o final do século XIX na Faculdade Nacional de Medicina que essa autora examinou.

Esse estigma que assinala prostitutas como pessoas imorais, potencialmente aptas a transmitir doenças sexualmente transmissíveis ou a cometer delitos constitui um triplo fundamento para a segregação, opondo limites à sexualidade

18 SIMÕES, Soraya Silveira. Vila Mimosa: etnografia da cidade cenográfica da prostituição carioca. Niterói: EdUFF, 2010, p. 45.

19 HOLTZ, Edson Leme. Noites Ilícitas: histórias e memórias da prostituição. Londrina: EDUEL, 2005, p. 206.

${ }^{20}$ KUSHNIR, Beatriz. Baile de Máscaras. Mulheres Judias e Prostituição. As Polacas e suas Associações de Ajuda Mútua. Rio de Janeiro, Imago, 1996, p. 28.

${ }^{21}$ RAGO, Margareth. Do cabaré ao lar: a utopia da cidade disciplinar: Brasil: 1890-1930. Rio de Janeiro: Paz e Terra, 1985, pp. 137-141. 
ROSA, Alexandre Morais da; BISPO, Andrea Ferreira. Prostituição: o impasse entre o Legalismo Moral e o Princípio do Dano. Revista Eletrônica Direito e Política, Programa de Pós-Graduação Stricto Sensu em Ciência Jurídica da UNIVALI, Itajaí, v.12, n.3, $3^{\circ}$ quadrimestre de 2017. Disponível em: www.univali.br/direitoepolitica - ISSN 1980-7791

das mulheres "normais" para que se distingam das "libertinas" e não sejam alvo dos mesmos perigos e desonra.

Entenda-se, portanto, que a criminalização da prostituição é um recado patriarcal: a sexualidade de todas as mulheres continua sendo rigidamente controlada.

\section{BREVE HISTÓRICO DA CRIMINALIZAÇÃO DA PROSTITUIÇÃo NO BRASIL}

O Código Criminal do Império ${ }^{22}$ não criminalizava a prostituição ou as condutas associadas a essa atividade. Desse modo, a lei penal somente podia intervir quando era imputada às prostitutas o crime de praticar qualquer ação que na opinião pública fosse considerada como ofensiva da moral e dos bons costumes.

$\mathrm{Na}$ quadratura de uma sociedade que se pretendia moderna, os discursos médicos que situavam a questão no campo da sexualidade pervertida e da criminalidade, passaram a reclamar a extensão das punições tanto para a prostituta quanto para aqueles que, de alguma forma, colaboravam com a atividade, sendo consideradas insuficientes a criminalização de duas modalidades de lenocínio pelo primeiro Código Penal republicano ${ }^{23}$.

Médicos e juristas, empenhados em debater a questão, assumiram o discurso de Tomás de Aquino sobre a prostituição ser um mal necessário, centrando-se a divergência entre aqueles que eram a favor $e$ os que eram contra a regulamentação das atividades afins.

Os regulacionistas, como lembra Soraya Simões, baseavam suas teses no trabalho do médico francês positivista Parent-Duchâtelet, segundo o qual, a "mulher se deixa levar mais facilmente pelas paixões e tem como principal

22 BRASIL. Código Criminal do Império do Brasil (Lei Imperial de 16 de dezembro de 1830). Disponível em http://www.planalto.gov.br/ccivil_03/leis/lim/LIM-16-12-1830.htm. Acesso em: 17 jun. 2017.

23

Código Penal (Decreto n. 847, de 11 de outubro de 1890). Disponível em: http://legis.senado.gov.br/legislacao/ListaPublicacoes.action?id=66049. Acesso em 17 jun. 2017. 
ROSA, Alexandre Morais da; BISPO, Andrea Ferreira. Prostituição: o impasse entre o Legalismo Moral e o Princípio do Dano. Revista Eletrônica Direito e Política, Programa de Pós-Graduação Stricto Sensu em Ciência Jurídica da UNIVALI, Itajaí, v.12, n.3, $3^{\circ}$ quadrimestre de 2017. Disponível em: www.univali.br/direitoepolitica - ISSN 1980-7791

característica a passividade, tornando-se presa fácil nas mãos daqueles que queiram explorá-la"24.

Esse fundamento demonstra que a criminalização das condutas subjacentes à prostituição é reflexo do totalitarismo patriarcal, que classifica, diagnostica e patologiza a sexualidade das mulheres partindo da premissa de que todas elas são prostitutas em potencial, somente podendo ser salvas de uma vida infame se forem submetidas a uma boa educação moral e religiosa e afastadas de pessoas que possam induzi-las a se prostituírem.

Os regulacionistas, produtores de discursos fantasiosos, descreviam as relações sexuais que ocorriam nos cabarés como práticas sórdidas e abomináveis e explicavam que isso se dava por imposição, e para o lucro, de cafetinas e rufiões.

Segundo Rago ${ }^{25}$, essas falas sedimentaram no inconsciente coletivo a ideia de que as prostitutas ou eram vítimas de criminosos que exploravam sua natural fraqueza feminina ou seres intrinsecamente promíscuos em seus corpos e gostos. Quanto às segundas, os médicos argumentavam não haver qualquer solução, pois nem um vigoroso banho de lixívia seria capaz de limpar tamanha sujidade. Mas as primeiras poderiam ser salvas, desde que as casas de tolerância e os bordéis fossem registrados na polícia, vigiados pela administração e pelas autoridades sanitárias, tornando-se o mais próximo que seria possível de um ambiente doméstico burguês.

$\mathrm{Na}$ disputa entre regulacionistas e abolicionistas, venceu a moralidade hegemônica, que aliás não se deu ao trabalho de participar das discussões, pois com a aprovação da Lei Mello Franco ${ }^{26}$, em 1915, foi incluído no Código Penal de

${ }^{24}$ SIMÕES, Soraya Silveira. Vila Mimosa: etnografia da cidade cenográfica da prostituição carioca. Niterói: EdUFF, 2010, p. 43.

${ }^{25}$ RAGO, Margareth. Do cabaré ao lar: a utopia da cidade disciplinar: Brasil: 1890-1930. Rio de Janeiro: Paz e Terra, 1985, p. 92.

26 BRASIL. Lei Mello Franco (Lei 2.992, de 25 de setembro de 1915). Disponível em http://www2.camara.leg.br/legin/fed/lei/1910-1919/lei-2992-

25setembro1915774536publicacaooriginal-138024-pl.html. Acesso em 17 jun. 2017. 
ROSA, Alexandre Morais da; BISPO, Andrea Ferreira. Prostituição: o impasse entre o Legalismo Moral e o Princípio do Dano. Revista Eletrônica Direito e Política, Programa de Pós-Graduação Stricto Sensu em Ciência Jurídica da UNIVALI, Itajaí, v.12, n.3, $3^{\circ}$ quadrimestre de 2017. Disponível em: www.univali.br/direitoepolitica - ISSN 1980-7791

1890 o crime de manter ou explorar casas de tolerância ou destinadas a encontros clandestinos para fins sexuais, instaurando-se uma proibição que não concebia a liberdade de escolha dos envolvidos como excludente de ilicitude.

O Código Penal ${ }^{27}$ em vigor, mantendo essa tradição, tipifica os crimes de mediação para servir a lascívia de outrem, favorecimento à prostituição, casa de prostituição e rufianismo no Título VI, da Parte Especial, atualmente denominado Dos Crimes Contra a Dignidade Sexual.

\section{A INTERVENÇÃo DO ESTADO NA VIDA PRIVADA, SEGUNDO JOHN STUART MILL}

Para John Stuart Mill, definir quais comportamentos autorizam a intervenção do Estado e da opinião pública na vida privada requer a adoção de um critério que se estenda para além daquilo que em dado momento de seu percurso histórico uma sociedade qualifica como bem jurídico. Para evitar o autoritarismo do Estado ou da opinião pública, ele defende que "o único fim pelo qual a humanidade está autorizada, individual ou coletivamente, a interferir na liberdade de ação de qualquer um de seus integrantes é a autodefesa"28.

Ressaltando que tanto os processos de criminalização quanto o reproche social a comportamentos que destoam do senso comum são, em última instância, processos de exclusão, a partir da teoria de Stuart Mill sobre o princípio do dano, é possível delimitar sobre o que a norma jurídica penal e a opinião pública podem incidir.

Então, esse autor ${ }^{29}$ propõe que há duas condições indispensáveis ao desenvolvimento humano: a liberdade e a variedade de situações e na medida que as pessoas passam a ter fontes de informação únicas e a dirigirem suas

27 Código Penal (Decreto-Lei 2.848, de 07 de dezembro de 1940). Disponível em http://www.planalto.gov.br/ccivil_03/decreto-lei/Del2848compilado.htm. Acesso em: 17 jun. 2017.

28 MILL, John Stuart. Sobre a Liberdade. Tradução Denise Bottmann. Porto Alegre: L\&PM, 2016, p. 22.

${ }^{29}$ MILL, John Stuart. Sobre a Liberdade. Tradução Denise Bottmann. Porto Alegre: L\&PM, 2016, p. 105. 
ROSA, Alexandre Morais da; BISPO, Andrea Ferreira. Prostituição: o impasse entre o Legalismo Moral e o Princípio do Dano. Revista Eletrônica Direito e Política, Programa de Pós-Graduação Stricto Sensu em Ciência Jurídica da UNIVALI, Itajaí, v.12, n.3, $3^{\circ}$ quadrimestre de 2017. Disponível em: www.univali.br/direitoepolitica - ISSN 1980-7791

esperanças e seus temores para os mesmos objetos, por maiores que sejam as diferenças de posição social entre elas, há um processo de assimilação que corresponderá a uma moralidade universal, porém acrítica, cuja pretensão maior é a eliminação da diferença pela adoção do senso comum.

A tentativa de criminalizar uma ofensa a um sentimento se dá, explica Mill ${ }^{30}$, porque a média geral da humanidade é moderada não apenas no intelecto, mas também nas inclinações. Ou seja, não tendo gostos ou desejos fortes o suficiente para levá-las a fazer algo inusitado, não entendem aqueles que os tem e os realizam, passando então a produzir discursos que supostamente pretendem levar os comportamentos dissonantes à regularidade.

Com esse espírito "filantrópico", a sociedade não apenas prescreve normas gerais de comportamento e se empenha para que todos atuem conforme o padrão aprovado, mas também destaca as características que imprimem a diferença de determinados indivíduos como traços de personalidade desviante e, quando não é capaz de eliminá-los, "passa a empreender medidas que restringem a possibilidade de atuação autônoma desses sujeitos"31.

Assim, segundo Mill32, a tolerância por parte do sentimento público se estende apenas aos gostos e modos de vida que tem a concordância da multidão, ou seja, quando o número de pessoas que gostam ou desgostam de determinada coisa é grande demais para ser reprimida.

Ocorre que a liberdade é correlata à autonomia e inerente à dignidade da pessoa humana, de modo que cada indivíduo deve ter ao seu dispor a possibilidade de definir o que é digno para si mesmo e de agir conforme esse entendimento. Qualquer obstáculo que seja oposto à execução de um projeto individual de vida

30 MILL, John Stuart. Sobre a Liberdade. Tradução Denise Bottmann. Porto Alegre: L\&PM, 2016, p. 124.

31 MILL, John Stuart. Sobre a Liberdade. Tradução Denise Bottmann. Porto Alegre: L\&PM, 2016, pp. 107-108.

32 MILL, John Stuart. Sobre a Liberdade. Tradução Denise Bottmann. Porto Alegre: L\&PM, 2016, p. 123. 
ROSA, Alexandre Morais da; BISPO, Andrea Ferreira. Prostituição: o impasse entre o Legalismo Moral e o Princípio do Dano. Revista Eletrônica Direito e Política, Programa de Pós-Graduação Stricto Sensu em Ciência Jurídica da UNIVALI, Itajaí, v.12, n.3, $3^{\circ}$ quadrimestre de 2017. Disponível em: www.univali.br/direitoepolitica - ISSN 1980-7791

boa, sem que esse projeto atinja direitos alheios, é ilegítimo.

Em outras palavras, a intenção de que todas as pessoas orientem seus pensamentos e condutas pelas mesmas máximas e normas torna uma sociedade autoritária. Entretanto, o que nos define como indivíduos e como sociedade é a nossa capacidade de exigir dignidade e legalidade no tratamento dos divergentes. O compromisso com o processo civilizatório é árduo e demanda o melhor de nós: compreender que o limite entre a soberania do indivíduo sobre si próprio e a autoridade da sociedade para questionar comportamentos individuais está em não se admitir a possibilidade de intervenção "naquilo que deve pertencer à parte da vida na qual o indivíduo é o principal interessado"33.

Assim, o princípio do dano serve como referencial para que não haja interferência na liberdade individual, seja pela criminalização de condutas seja pela inexistência de regulamentação de atividades profissionais consideradas moralmente reprováveis, mas que afetam tão somente os interesses do próprio indivíduo.

Para enfatizar os limites do que pode ser considerado uma lesão a direitos de terceiros, John Stuart Mill apresenta diversas situações problema. Tomaremos três delas para abordar possíveis justificativas para reprovar, moral ou legalmente, a prostituição.

Na primeira situação, Mill fala dos atos de alguém que podem afetar o senso moral de algumas pessoas sem, contudo, violar seus direitos. Trata-se, precisamente, daquelas condutas que, embora não sejam consideradas crime, como é o caso da prostituição em si mesma, a moralidade hegemônica reprova. Para ele, o ofensor não pode ser reprovado pela opinião pública quando sua conduta "não afeta os interesses de ninguém, além de si mesmo, ou não precisa afetá-los, a menos que as pessoas assim o queiram" ${ }^{134}$.

\footnotetext{
33 Ibidem, p. 33.

${ }^{34}$ MILL, John Stuart. Sobre a Liberdade. Tradução Denise Bottmann. Porto Alegre: L\&PM, 2016, p. 116.
} 
ROSA, Alexandre Morais da; BISPO, Andrea Ferreira. Prostituição: o impasse entre o Legalismo Moral e o Princípio do Dano. Revista Eletrônica Direito e Política, Programa de Pós-Graduação Stricto Sensu em Ciência Jurídica da UNIVALI, Itajaí, v.12, n.3, $3^{\circ}$ quadrimestre de 2017. Disponível em: www.univali.br/direitoepolitica - ISSN 1980-7791

Mill defende que mesmo que as escolhas de alguém possam ser danosas a ela mesma, deve haver liberdade legal e social para que ela pratique essas ações, porque "ninguém está autorizado a dizer a outra criatura humana na maturidade que ela não deve fazer com sua vida o que escolher fazer"35.

Para ele, o interesse que a sociedade tem em qualquer pessoa é ínfimo e totalmente indireto, se comparado ao interesse que a própria pessoa tem em si mesma. Por isso, qualquer prejuízo que alguém venha a sofrer como consequência de suas escolhas é insignificante se comparado à possibilidade de que a sociedade interfira na liberdade de escolha. Assim, somente

Invadir os direitos do outro, infligir-lhe qualquer dano ou prejuízo não justificado por seus próprios direitos, lançar mão de falsidade ou duplicidade ao tratar com terceiros, aproveitar-se de modo injusto ou mesquinho de vantagens sobre eles, e mesmo se abster egoisticamente de defendêlos contra lesões são objetos adequados de reprovação moral e, em casos graves, de punição e indenização moral ${ }^{36}$.

Destarte, "os chamados deveres para consigo mesmo não são socialmente obrigatórios, a menos que as circunstâncias os tornem também deveres para com os outros"37.

Há, portanto, um limite claro entre a perda de consideração e a reprovação, pois ninguém é obrigado a gostar de uma pessoa que o desagrada, mas nem por isso está autorizado a tornar a vida de tal pessoa penosa. A universalidade da igual dignidade permite que alguém seja objeto de piedade ou de desapreço, mas não de raiva ou de ressentimento. Ninguém pode ser considerado inimigo da sociedade em razão de suas escolhas individuais se essas escolhas afetam apenas o próprio indivíduo.

35 MILL, John Stuart. Sobre a Liberdade. Tradução Denise Bottmann. Porto Alegre: L\&PM, 2016, p. 117.

${ }^{36}$ MILL, John Stuart. Sobre a Liberdade. Tradução Denise Bottmann. Porto Alegre: L\&PM, 2016, p. 120.

37 MILL, John Stuart. Sobre a Liberdade. Tradução Denise Bottmann. Porto Alegre: L\&PM, 2016, p. 121. 
ROSA, Alexandre Morais da; BISPO, Andrea Ferreira. Prostituição: o impasse entre o Legalismo Moral e o Princípio do Dano. Revista Eletrônica Direito e Política, Programa de Pós-Graduação Stricto Sensu em Ciência Jurídica da UNIVALI, Itajaí, v.12, n.3, $3^{\circ}$ quadrimestre de 2017. Disponível em: www.univali.br/direitoepolitica - ISSN 1980-7791

Mill ${ }^{38}$ também propõe que a pretensão de proteger a sociedade contra os maus exemplos que os "viciosos" ou "levianos" dão aos outros não justifica a interferência na autonomia, pois se a conduta causa dano ao próprio agente, o exemplo é, ao contrário, salutar, visto que mostra que as suas consequências são penosas e degradantes, desestimulando quem pretenda segui-lo.

Ele encerra seus argumentos contra a interferência do público em questões de moral individual acentuando que a opinião de uma maioria dominante, quando afirma que seus próprios interesses podem ser afetados por alguma conduta que se viesse a permitir, leva em conta apenas o que essa maioria acredita que "é bom ou ruim para as pessoas que integram as classes minoritárias" 39 . Ou seja, a maioria considera apenas as suas próprias preferências e desconsidera que a conduta que é objeto de censura tem o mesmo direito de se expressar.

Por isso, quando se fala de igual direito à liberdade, não é possível estabelecer um critério de aferição de certo e errado baseado na liberdade de uma pessoa de ter seu próprio projeto de vida e de outras pessoas que se sentem ofendidas com esse projeto.

Na segunda situação, Stuart Mill aborda a hipótese em que uma pessoa aconselha ou incita outra a praticar uma conduta que é considerada imprópria, mas que em todo caso só pode causar mal exclusivamente a quem a pratica.

Mill ${ }^{40}$ sugere que a ação de aconselhar ou incitar alguém é um ato social e que o que é permitido fazer é permitido aconselhar, logo, se há um modo de vida que se baseia na oposição ao que é considerado como bem público, mas essa oposição não é alvo da lei penal, e quem está sendo aconselhado ou incitado age dentro da sua esfera de liberdade e tem ciência de que o mal resultante de suas

38 MILL, John Stuart. Sobre a Liberdade. Tradução Denise Bottmann. Porto Alegre: L\&PM, 2016, p. 148.

39 MILL, John Stuart. Sobre a Liberdade. Tradução Denise Bottmann. Porto Alegre: L\&PM, 2016, p. 149.

40 MILL, John Stuart. Sobre a Liberdade. Tradução Denise Bottmann. Porto Alegre: L\&PM, 2016, p. 151. 
ROSA, Alexandre Morais da; BISPO, Andrea Ferreira. Prostituição: o impasse entre o Legalismo Moral e o Princípio do Dano. Revista Eletrônica Direito e Política, Programa de Pós-Graduação Stricto Sensu em Ciência Jurídica da UNIVALI, Itajaí, v.12, n.3, $3^{\circ}$ quadrimestre de 2017. Disponível em: www.univali.br/direitoepolitica - ISSN 1980-7791

ações recairá sobre ela própria, não há justificativa para a intervenção.

A última situação desloca o ponto de observação para a figura de qualquer pessoa que, tendo incitado alguém à prostituição, obtém lucros com a mediação dos serviços sexuais, hipótese em que surge um complicador que situa os exatos limites entre os princípios do dano e da liberdade individual.

Antevendo as objeções que poderiam ser formuladas à prevalência da autonomia, Mill ${ }^{41}$ propõe que a favor da intervenção poderia ser argumentado que mesmo não sendo da competência do Estado decidir, para fins de repressão, se uma conduta afeta apenas os interesses do indivíduo, essa intervenção estaria plenamente justificada para eliminar a possibilidade de que 0 incitador promova seus objetivos pessoais às custas de outra pessoa.

Ele responde a esse argumento dizendo que ele não é suficiente para "justificar a anomalia moral de punir o acessório enquanto o principal fica (e deve ficar) em liberdade, de multar ou prender o cafetão, mas não o cliente"42.

Em todo caso, no contexto que ele aborda essa questão, o interesse em torno do assunto perpassava pelas mesmas questões que mobilizaram a atenção de médicos e juristas brasileiros no início do século $X X$, de onde se pode concluir que ele admitiria a fiscalização sanitária dos prostíbulos, mas não a fiscalização moral ou a criminalização dos atores que investem na atividade ou que prestam serviços mediatos à prostituição.

Essa afirmação tem por base o fato de que, por diversas vezes, Mill ${ }^{43}$ sustenta que não está tentando erguer barreiras contra males imaginários, mas sim evidenciar que a ampliação das fronteiras daquilo que se pode chamar de policiamento moral, ao ponto de invadir a liberdade mais inquestionavelmente

41 MILL, John Stuart. Sobre a Liberdade. Tradução Denise Bottmann. Porto Alegre: L\&PM, 2016, p. 152.

42 MILL, John Stuart. Sobre a Liberdade. Tradução Denise Bottmann. Porto Alegre: L\&PM, 2016, p. 152.

43 MILL, John Stuart. Sobre a Liberdade. Tradução Denise Bottmann. Porto Alegre: L\&PM, 2016, p. 152. 
ROSA, Alexandre Morais da; BISPO, Andrea Ferreira. Prostituição: o impasse entre o Legalismo Moral e o Princípio do Dano. Revista Eletrônica Direito e Política, Programa de Pós-Graduação Stricto Sensu em Ciência Jurídica da UNIVALI, Itajaí, v.12, n.3, $3^{\circ}$ quadrimestre de 2017. Disponível em: www.univali.br/direitoepolitica - ISSN 1980-7791

legítima do indivíduo, é uma das propensões humanas mais universais.

Portanto, proibir uma conduta que se considera imoral ou nociva à saúde ou à liberdade requer que os danos a ela atribuídos sejam verificáveis, e não presumíveis ou supostos. Se um comportamento não viola qualquer dever específico para com o público e não ocasiona prejuízo a indivíduo identificável, cuja vontade ou liberdade teria sido restrita, o que há, no máximo, é uma inconveniência que a sociedade deve tolerar por consideração ao bem maior da liberdade humana.

\section{COMO SÃO EXPLICADOS OS INTERDITOS OPOSTOS À PROSTITUIÇÃO}

Do mesmo modo que ocorria sob a vigência do Código Criminal do Império, as prostitutas brasileiras continuam sendo punidas indiretamente, pois no processo de criminalização secundária são atingidas sem qualquer critério, seja porque os instrumentos de controle e de fiscalização formais incidem sobre os profissionais para os quais trabalham ou sobre aqueles que lhes prestam serviços, seja porque a elas são imputadas a prática de condutas extraídas da interseção entre o estigma delinquencial que as assinala e as atividades que se desenrolam no entorno, o que dá azo às conduções arbitrárias à delegacias de polícia, agressões físicas e extorsões, como ilustram o livro Filha, Mãe, avó e puta, de Gabriela Leite $^{44}$ e a Ata da Audiência Pública da Comissão de Defesa dos Direitos Humanos e Cidadania em conjunto com Comissão de Defesa dos Direitos da Mulher realizada pela Assembleia Legislativa do Rio de Janeiro em 06 de abril $2014^{45}$.

Há ainda o problema da violência simbólica, pois da criminalização das condutas envolventes à prostituição decorre diretamente a impossibilidade de que a profissão seja regulamentada, o que implica em desrespeito aos valores sociais

44 LEITE, Gabriela. Filha, Mãe, avó e puta. Rio de Janeiro: Objetiva, 2009.

45 RIO DE JANEIRO. Assembleia Legislativa. Comissão de Defesa dos Direitos Humanos e Cidadania. Comissão de Defesa dos Direitos da Mulher. Audiência Pública realizada em 06 abr. 2014. Disponível

em: http://alerjln1.alerj.rj.gov.br/compcom.nsf/e36c0566701326d503256810007413ca/e2d2376350a1 e9f283257d1c00556eba?OpenDocument. Pesquisa realizada em 17 jun. 2017. 
ROSA, Alexandre Morais da; BISPO, Andrea Ferreira. Prostituição: o impasse entre o Legalismo Moral e o Princípio do Dano. Revista Eletrônica Direito e Política, Programa de Pós-Graduação Stricto Sensu em Ciência Jurídica da UNIVALI, Itajaí, v.12, n.3, $3^{\circ}$ quadrimestre de 2017. Disponível em: www.univali.br/direitoepolitica - ISSN 1980-7791

do trabalho e da livre iniciativa, quarto fundamento da República Federativa do Brasil $^{46}$.

De outro lado, o estigma social contra a prostituta expressa, "de modo aberto, porque estigmatizado, toda uma violência simbólica dirigida, de modo velado e nunca admitido, às mulheres como um todo"47. Há uma crença, arraigada no imaginário coletivo, de que o corpo feminino é uma arma usada para alcançar diversos objetivos contra os pobres homens, que não são capazes de resistir a essa artimanha. Assim, ao ser projetada na prostituta uma sexualidade pulsional, sem que disso decorra seu reconhecimento enquanto sujeito, ocorre como que uma privatização masculina da satisfação dos desejos, negando-se à todas as mulheres o direito de exercerem sua sexualidade sem os compromissos e as obrigações morais que regem as expectativas de comportamento feminino e masculino.

Verifica-se, assim, que a intervenção do Estado, através do Direito Penal, está intrinsecamente ligada à opinião pública, que não reconhece a validade da prostituição, enquanto profissão e projeto de vida.

Apresentado esse quadro, a indagação que surge é se a intervenção penal e social se justifica face ao conteúdo dos Direitos Fundamentais da pessoa humana, dentre estes o direito à liberdade.

Para responder a essa pergunta, tem-se, inicialmente, que no regime jurídico brasileiro a tutela penal visa a proteção de um bem, que é o referencial dogmático e político-criminal a partir do qual serão delimitadas as condutas incriminadas e aquelas que, mesmo não sendo incriminadas, não receberão a proteção jurídica deferida a outras categorias.

A definição do que consistiria esse bem que autoriza a intervenção do Estado,

46 BRASIL. Constituição da República Federativa do Brasil. Promulgada em 05 de outubro de 1988. Publicada no Diário Oficial da União de 05.10.1988. Disponível em https://www.parlamento.pt/Parlamento/Documents/CRP-1822.pdf

47 SOUZA, Jessé. Ralé Brasileira: quem é e como Vive. Belo Horizonte: Editora UFMG, 2009, p. 174. 
ROSA, Alexandre Morais da; BISPO, Andrea Ferreira. Prostituição: o impasse entre o Legalismo Moral e o Princípio do Dano. Revista Eletrônica Direito e Política, Programa de Pós-Graduação Stricto Sensu em Ciência Jurídica da UNIVALI, Itajaí, v.12, n.3, $3^{\circ}$ quadrimestre de 2017. Disponível em: www.univali.br/direitoepolitica - ISSN 1980-7791

ou, para adotar o marco de John Stuart Mill, qual espécie de ofensa justifica essa intervenção, mobilizou os debates de clássicos e positivistas em torno das doutrinas do livre arbítrio e do determinismo como conteúdo do delito. Posteriormente, a partir da conceituação de crime como violação ou exposição a perigo de um bem garantido a todos pelo poder do Estado, proposta por Feurbach e Birnbaum, chegou-se à definição de Welzel ${ }^{48}$, para o qual os bens jurídicos são interesses individuais e coletivos primordiais ao bom funcionamento de uma comunidade e que, por isso, devem ser protegidos pela imposição de valores ético-sociais aos comportamentos humanos.

Assim, em regimes jurídicos de tradição romano-germânica, os bens jurídicos corresponderiam aos interesses humanos cuja proteção seria indispensável à ordem social, de onde se extrai tanto um limite dogmático - no ponto em que não é possível extrapolar o tipo penal para criminalizar uma conduta não prevista em lei -, quanto uma diretriz da política criminal, tendo em vista que a seleção e determinação dos bens individuais e coletivos que merecem a proteção do direito penal serão pautadas pela indispensabilidade desses bens à comunidade humana.

A partir desse preceito, o moralismo legal, segundo o qual é legítimo criminalizar condutas ou não regulamentar atividades consideradas puramente imorais mesmo que não causem lesões ou ofensas a outras pessoas -, cede diante de modelos fundados no liberalismo legal defendido por John Stuart Mill, pois aqui a única razão para a proibição criminal de condutas, ou a negativa de regulamentação e proteção a atividades privadas, é a necessidade de prevenir lesões ou ofensas a terceiros.

Em que pese esse preceito ser suficientemente claro e facilmente compreensível em um Brasil que consolidou sua independência sob a ordem de uma Constituição inspirada na doutrina liberal do francês Benjamin Constant, no Código Penal de 1890 , os delitos relacionados à prostituição foram colocados entre os crimes contra a segurança da honra e honestidade das famílias e do

48 WELZEL, Hans. Derecho Penal Alemán: Parte Geral. $4^{a}$ ed. Santiago do Chile: Jurídica de Chile, 1997, p. 5. 
ROSA, Alexandre Morais da; BISPO, Andrea Ferreira. Prostituição: o impasse entre o Legalismo Moral e o Princípio do Dano. Revista Eletrônica Direito e Política, Programa de Pós-Graduação Stricto Sensu em Ciência Jurídica da UNIVALI, Itajaí, v.12, n.3, $3^{\circ}$ quadrimestre de 2017. Disponível em: www.univali.br/direitoepolitica - ISSN 1980-7791

ultraje público ao pudor e no Código Penal de 1941 no Capítulo dos crimes contra os costumes.

Nenhum desses diplomas informa quais bons costumes seriam esses, ou seja, quais seriam os bens jurídicos por eles tutelados. Tampouco essa informação está disponível na justificativa da Lei 12.015/2009, que alterou parcialmente os artigos 227 a 230 e o nome do capítulo no qual eles se encontram inseridos para "Dos Crimes Contra a Dignidade Sexual"49.

Entretanto, o exame dos enunciados dos tipos penais pode esclarecer o que viriam a ser esses bons costumes e essa dignidade sexual.

Sobre o costume, John Stuart Mill, afirma que as pessoas de qualquer sociedade percebem as regras em uso no seu meio como evidentes e justificáveis por si mesmas, uma ilusão que decorre da influência do hábito, "o qual não só é uma segunda natureza, como diz o provérbio, mas também é constantemente confundido com a primeira natureza"50.

O efeito do "costume", acrescenta ele, é evitar qualquer dúvida sobre as regras de conduta que os homens impõem à atividade alheia, "e esse efeito é tanto mais cabal por se tratar de um assunto sobre o qual geralmente não se considera necessário apresentar razões, seja aos outros, seja a si mesmo" ${ }^{51}$.

A crença de que há determinados valores morais que, longe de derivarem da metafísica ou de inferências empíricas mal-sustentadas, são auto-evidentes, tem sido legitimada por teóricos jusnaturalistas desde Tomás de Aquino a John Finnis ${ }^{52}$, o que introduz a percepção, equivocada, de que o princípio prático que

49 Código Penal (Decreto-Lei 2.848, de 07 de dezembro de 1940). Disponível em http://www.planalto.gov.br/ccivil_03/decreto-lei/Del2848compilado.htm. Acesso em: 17 jun. 2017.

50 MILL, John Stuart. Sobre a Liberdade. Tradução Denise Bottmann. Porto Alegre: L\&PM, 2016, p. 17

51 MILL, John Stuart. Sobre a Liberdade. Tradução Denise Bottmann. Porto Alegre: L\&PM, 2016, p. 17

52 FINNIS, John Mitchell. Lei Natural e Direitos Naturais. Tradução de Leila Mendes. São Leopoldo: Unisinos, 2007. 
ROSA, Alexandre Morais da; BISPO, Andrea Ferreira. Prostituição: o impasse entre o Legalismo Moral e o Princípio do Dano. Revista Eletrônica Direito e Política, Programa de Pós-Graduação Stricto Sensu em Ciência Jurídica da UNIVALI, Itajaí, v.12, n.3, $3^{\circ}$ quadrimestre de 2017. Disponível em: www.univali.br/direitoepolitica - ISSN 1980-7791

guia uma pessoa em suas opiniões sobre a regulação da conduta humana sobre o que é ou não adequado é universal.

Porém, conforme assinala Mill, quando sentimentos sobre qualquer assunto são melhores que quaisquer justificativas e as tornam supérfluas, o que se tem como motivos para a imposição de interditos são apenas opiniões pessoais - ainda que partilhadas por um número significativo de pessoas -, sobre noções de moral, gosto ou decoro. Qualquer argumentação que se apresente contra esses sentimentos, por mais sólida que seja, "não apenas não a enfraquece como a torna mais forte"53.

Assim, as opiniões humanas sobre o que é bom ou ruim, louvável ou reprovável "são afetadas por todas as múltiplas causas que influem em seus desejos em relação à conduta dos outros, e são tão numerosas quanto as que determinam seus desejos em qualquer outro assunto" 54 , de modo que refletirão, às vezes, uma racionalidade, mas em outras tantas serão apenas reproduções de preconceitos, superstições, afetos sociais e antissociais, ciúme, inveja, arrogância, desdém, receios e interesses próprios, legítimos ou ilegítimos.

Com essas matrizes, não se pode avalizar um costume como bom ou ruim sem prejuízo à liberdade de quem, embora não os observe, não causa com isso qualquer prejuízo a outras pessoas.

Além disso, há o problema de que normas legais fundadas em uma suposta tutela aos bons costumes não preenchem o requisito da taxatividade, pois não descrevem todos os elementos empíricos que consistiriam a conduta incriminada.

Efetivamente. A partir de uma tutela a um bem abstrato e sem a descrição taxativa, foi possível, sob a vigência do Código Criminal do Império, ${ }^{55}$ que o simples ingresso de prostitutas em lugares públicos fosse considerado uma

53 MILL, John Stuart. Sobre a Liberdade. Tradução Denise Bottmann. Porto Alegre: L\&PM, 2016, p. 226.

${ }^{54}$ Ibidem, p. 18.

55 Ibidem. 
ROSA, Alexandre Morais da; BISPO, Andrea Ferreira. Prostituição: o impasse entre o Legalismo Moral e o Princípio do Dano. Revista Eletrônica Direito e Política, Programa de Pós-Graduação Stricto Sensu em Ciência Jurídica da UNIVALI, Itajaí, v.12, n.3, $3^{\circ}$ quadrimestre de 2017. Disponível em: www.univali.br/direitoepolitica - ISSN 1980-7791

ofensa aos "bons costumes" e que prover a subsistência por meio da prostituição levasse ao mesmo resultado incriminador, pois segundo o artigo 280, constituía crime toda ação que, na opinião publica, fosse considerada como evidentemente ofensiva da moral e dos bons costumes.

Essa situação se repetiu sob a vigência do primeiro Código Penal da República ${ }^{56}$, dado que aqui a liberdade de ir e vir também podia ser interpretada como "exibições impudicas", atentatórias do pudor, que, sem ofensa à honestidade individual de pessoa, ultrajam e escandalizam a sociedade.

O uso de categorias como "desejos desonestos" e "paixões lascivas" (artigo 277) e a criminalização da conduta de quem presta "assistência, habitação e auxílios" para que uma mulher aufira lucro da prostituição (artigo 278), demonstra que, sob a forte influência dos dogmas patriarcais, o Código Penal de 1890 explicitou, em uma suposta defesa da moralidade, que as mulheres deveriam optar entre o casamento e a criminalidade, pois, em uma sociedade na qual elas tinham poucas alternativas de trabalho, exercer livremente a sexualidade era, também, uma forma de adquirir independência financeira, o que, naturalmente, não era concebível, já que todo o arcabouço normativo as submetia à tutela masculina.

Mantendo essa visão, o Código Penal de $1940^{57}$, ainda em vigor, reproduziu os dispositivos que associaram a prostituição à criminalidade nos artigos 227, 228, 229 e 230, harmonizando-se com as disposições do Código Civil de 191658, que transformou a força física do homem em poder pessoal e autoridade, outorgando-Ihe o comando exclusivo da família e proibindo que as mulheres trabalhassem sem a autorização dos maridos.

Mantida a descrição das condutas, a mudança de nomenclatura do capítulo onde

56 Código Penal (Decreto-Lei 2.848, de 07 de dezembro de 1940). Disponível em http://www.planalto.gov.br/ccivil_03/decreto-lei/Del2848compilado.htm. Acesso em: 17 jun. 2017

57 Código Penal (Decreto-Lei 2.848, de 07 de dezembro de 1940). Disponível em http://www.planalto.gov.br/ccivil_03/decreto-lei/Del2848compilado.htm. Acesso em: 17 jun. 2017

58 BRASIL. Código Civil (Lei no 3.071, de $1^{\circ}$ de janeiro de 1916). Disponível em http://www.planalto.gov.br/ccivil_03/leis/L3071.htm. Acesso em 17 jun. 2017. 
ROSA, Alexandre Morais da; BISPO, Andrea Ferreira. Prostituição: o impasse entre o Legalismo Moral e o Princípio do Dano. Revista Eletrônica Direito e Política, Programa de Pós-Graduação Stricto Sensu em Ciência Jurídica da UNIVALI, Itajaí, v.12, n.3, $3^{\circ}$ quadrimestre de 2017. Disponível em: www.univali.br/direitoepolitica - ISSN 1980-7791

se encontram os crimes relacionados à prostituição consentida para "Dos Crimes Contra a Dignidade Sexual", não encobre os valores que de fato conduziram à opção pela tipicidade: a perpétua tentativa de classificar as mulheres em boas e más, subjugando ambas categorias por meio da criminalização da liberdade sexual, agora com o argumento de que se está a tratar de Direitos Humanos.

Desse modo, aceitar que a criminalização implica em proteção à dignidade humana contra um ato em que uma pessoa é colocada como objeto de outra pessoa, é abdicar da necessidade de motivação tanto quanto se fazia quando se tratava de aceitar o costume como argumento único para a punição.

Em primeiro lugar, porque tal restrição, levada às últimas instâncias, impede que um indivíduo disponha do próprio corpo como bem entender, o que naturalmente não é tarefa do Estado impedir.

Em segundo lugar, porque o importante não é como a sociedade concebe a prostituição, mas sim como prostitutas, no pleno gozo de sua autonomia individual, se entendem como sujeitos nessa relação. Para muitas e muitos profissionais do sexo, não se trata absolutamente de uma venda do corpo, ou aluguel, se assim se preferir, mas da prestação de um serviço como outro qualquer, conforme defendeu Lourdes Barreto ${ }^{59}$ em discurso perante a Comissão Parlamentar de Inquérito do Tráfico de Pessoas no Brasil em 13 de agosto de 2013.

Ademais, a partir do princípio do dano, tem-se que reconhecer que as referências individuais sobre o que é dignidade são as únicas que podem operar como critério de valoração de uma atividade que diz respeito unicamente aos envolvidos. Veja-se que John Stuart Mill, embora defensor da busca de sentimentos e atitudes elevados, afirma que adultos não devem ser punidos, por

59 BRASIL. Câmara dos Deputados. Comissão Parlamentar de Inquérito do Tráfico de Pessoas no Brasil. Audiência Pública realizada em 13 ago. 2013. Disponível em http://www2.camara.leg.br/atividade-legislativa/comissoes/comissoes-temporarias/parlamentarde-inquerito/54a-legislatura/cpi-trafico-de-pessoas-no-brasil/documentos/notastaquigraficas/nt130813-tpb. Acesso em 9 jun. 2017. 
ROSA, Alexandre Morais da; BISPO, Andrea Ferreira. Prostituição: o impasse entre o Legalismo Moral e o Princípio do Dano. Revista Eletrônica Direito e Política, Programa de Pós-Graduação Stricto Sensu em Ciência Jurídica da UNIVALI, Itajaí, v.12, n.3, $3^{\circ}$ quadrimestre de 2017. Disponível em: www.univali.br/direitoepolitica - ISSN 1980-7791

meios legais ou morais, por supostamente não saberem cuidar adequadamente de si próprios, até porque a sociedade dispõe de meios de elevar seus membros mais fracos até o seu padrão ordinário de conduta racional. Assim, para ele,

A menos que queiramos adotar a lógica dos perseguidores e dizer que podemos perseguir os outros, porque estamos certos, e que eles não podem nos perseguir, porque estão errados, é melhor que nos acautelemos para não aceitar um princípio que, se fosse aplicado a nós mesmos, sentiríamos como uma grande injustiça ${ }^{60}$.

De outro lado, a teoria da prostituição como conduta criminosa pressupõe que o homem só pode satisfazer seus desejos sexuais heterodoxos se puder contar com o auxílio de uma mulher delinquente, o que implica na adoção pelo Estado da categorização de mulher adequada e inadequada ao casamento, ou seja, em valoração moral incompatível com a garantia da igualdade e o objetivo de reduzir os processos de marginalização e de exclusão social previstos no artigo 30, I, III e IV da Constituição Federal de 1988.

Outro argumento para a criminalização, defendido por Tulio Padovani61, é o de que, no mundo capitalista, a prostituição transforma o corpo humano em um bem do mercado, situação incompatível com a dignidade da pessoa humana, pois é inadmissível que os corpos humanos fiquem sujeitos às leis da oferta e da procura. Nesses termos, a normatização da prostituição como trabalho seria uma forma de degradação do ser humano.

Para os que defendem essa tese, prostitutas, intermediários, empresários do ramo e clientes devem ter suas condutas criminalizadas, porque assim se espera que esses sujeitos possam ser levados a optar por outros meios de satisfação econômica e pessoal.

Esse argumento merece duas observações.

60 MILL, John Stuart. Sobre a Liberdade. Tradução Denise Bottmann. Porto Alegre: L\&PM, 2016, pp. 131-132.

61 PADOVANI, Tulio. Il testo único sull'immigrazione e le strategie di contrasto allo sfruttamento sessuale: I'innovazione legislativa del programma di protezione sociale e I'impatto prodotto nel contesto sociale. In: Stop tratta: Atti del Convegno Internazionale. Bologna, 23/24 de maggio de 2002. Martinsicuro: On The Road Edizioni, 2002, p. 50. 
ROSA, Alexandre Morais da; BISPO, Andrea Ferreira. Prostituição: o impasse entre o Legalismo Moral e o Princípio do Dano. Revista Eletrônica Direito e Política, Programa de Pós-Graduação Stricto Sensu em Ciência Jurídica da UNIVALI, Itajaí, v.12, n.3, $3^{\circ}$ quadrimestre de 2017. Disponível em: www.univali.br/direitoepolitica - ISSN 1980-7791

Primeira. O problema de compreender o mundo a partir de estereótipos é que isso limita os horizontes cognitivos. Pensar nas prostitutas como objeto é contribuir para com os mecanismos de fundo que as colocam em situação de vulnerabilidade e de emergência social, desconsiderando suas lutas e a validade de suas escolhas individuais.

Segunda. Ver na prostituta uma vítima do capitalismo é desconsiderar que as leis do mercado regem todas as profissões, por isso ninguém é completamente livre para escolher com o que trabalhar. Cada um trabalha com o que pode/quer e a absoluta maioria das pessoas, tanto quanto as prostitutas, está vendendo sua força de trabalho. Em uma ordem global neoliberal, poucos têm a dignidade plenamente respeitada no empreendimento de manter a própria subsistência.

Desse modo, se a prostituta mantém um contrato de trabalho que considera satisfatório, seja com os clientes seja com os proprietários dos prostíbulos, sua condição não implica em expropriação da força de trabalho maior do que há em qualquer outra profissão.

Por outro prisma, a pretensão de defender prostitutas contra si mesmas, quando milhões de trabalhadores e trabalhadoras no mundo, submetidos a condições de trabalho degradantes, clamam por ajuda, revela antes uma antipatia instintiva à prostituição do que uma real preocupação com os Direitos Humanos.

Por fim, pode-se argumentar que se trata de uma profissão de risco e que, portanto, expõe os envolvidos a situações perigosas.

A isso responde-se afirmando que tais problemas se devem a fatores externos, pois a falta de segurança seria eliminada se a prostituição não fosse uma atividade clandestina.

Não nos deixemos enganar, "o essencial não são todos esses escrúpulos, o moralismo que revelam, ou a hipocrisia que neles podemos vislumbrar, mas sim 
ROSA, Alexandre Morais da; BISPO, Andrea Ferreira. Prostituição: o impasse entre o Legalismo Moral e o Princípio do Dano. Revista Eletrônica Direito e Política, Programa de Pós-Graduação Stricto Sensu em Ciência Jurídica da UNIVALI, Itajaí, v.12, n.3, $3^{\circ}$ quadrimestre de 2017. Disponível em: www.univali.br/direitoepolitica - ISSN 1980-7791

a necessidade reconhecida de que é preciso superá-los"62.

A repressão vem sendo aceita ao longo do tempo porque, nas relações de poder, "a sexualidade não é o elemento mais rígido, mas um dos dotados de maior instrumentalidade, utilizável no maior número de manobras e podendo servir de ponto de apoio e de articulação às mais variadas estratégias"63.

Na lógica da moralidade hegemônica, não são considerados os discursos que relegaram a sexualidade das mulheres à obscuridade e ao mutismo e tampouco que é a partir disso que são opostos interditos que mantém um rígido núcleo de princípios que pré-seleciona quantas e quais são as pessoas que deverão ter seus direitos respeitados.

A afirmação dogmática da liberdade individual nesses termos é meramente discursiva, uma bricolagem falsamente neutra de uma reflexão teórica, pois as normas penais são formuladas a partir de proposições engendradas por razões econômicas ou políticas que resguardam os privilégios patriarcais, os quais de modo algum se pretendeu, ou se pretende, compartilhar com as mulheres.

A percepção social acrítica sobre a necessidade da criminalização, portanto, não decorre de um processo arbitrário de interpretação do mundo. Ao contrário, ela resulta da secular eleição de critérios discursivos que induziram os instrumentos cognitivos humanos não só a não enxergar as contradições internas do modelo patriarcal, mas principalmente a internalizá-lo a tal ponto que lhe seja incompreensível sequer pensar que viver fora da tríade propriedade, família e religião é possível.

Ignora-se, assim, que a marginalização de determinadas classes de indivíduos não é auto-constitutiva, mas decorre de condições sociais e econômicas desiguais e excludentes, ratificadas pelo estigma de que as

62 FOUCAULT, Michel. História da Sexualidade 1, A Vontade de Saber. Rio de Janeiro/São Paulo: Paz \& Terra, 2015, p. 27.

63 FOUCAULT, Michel. História da Sexualidade 1, A Vontade de Saber. Rio de Janeiro/São Paulo: Paz \& Terra, 2015, p. 29. 
ROSA, Alexandre Morais da; BISPO, Andrea Ferreira. Prostituição: o impasse entre o Legalismo Moral e o Princípio do Dano. Revista Eletrônica Direito e Política, Programa de Pós-Graduação Stricto Sensu em Ciência Jurídica da UNIVALI, Itajaí, v.12, n.3, $3^{\circ}$ quadrimestre de 2017. Disponível em: www.univali.br/direitoepolitica - ISSN 1980-7791

prostitutas são despudoradas, libertinas e despidas de autorrespeito ou de que são vítimas de circunstâncias desfavoráveis e estão expiando seus pecados enquanto aguardam um homem compreensivo para tirá-las de uma vida infame.

Em Estados Democráticos, o Direito não pode exercer esse papel.

\section{DIREITOS INVIOLÁVEIS COMO PARÂMETRO PARA OS PROCESSOS DE CRIMINALIZAÇÃO PRIMÁRIA E SECUNDÁRIA}

No Brasil, o limite à legítima interferência da opinião coletiva na elaboração de normas incriminadoras e na regulamentação profissional não pode ser a moralidade hegemônica, pois o primeiro objetivo desta República é construir uma sociedade livre, justa e solidária64.

Dessa forma, a Política Criminal no Brasil deve ter por diretriz que a incidência do Direito Penal é sempre subsidiária, pois forçosamente irá restringir a liberdade individual, e que os bens jurídicos por ele protegidos devem ser aqueles que correspondam a valores constitucionais.

Entretanto, isso não significa que todos os interesses previstos na Constituição podem servir como substrato para a criminalização, pois, se assim o fosse, o direito penal perderia o seu caráter subsidiário. Daí a importância de se ter um critério para a aferição de quais bens correlatos aos valores constitucionais podem ser objeto da tutela penal.

Em primeiro lugar, a criminalização de condutas deve atender ao princípio da lesividade, ou seja, deve ter por pressuposto "uma lesão efetiva ou um perigo concreto de lesão do bem jurídico"65 considerado indispensável para manter condições mínimas de convivência social.

\footnotetext{
64 BRASIL. Constituição da República Federativa do Brasil. Promulgada em 05 de outubro de 1988. Publicada no Diário Oficial da União de 05.10.1988. Disponível em https://www.parlamento.pt/Parlamento/Documents/CRP-1822.pdf. Acesso em 9 jun. 2017.
}

65 TAVARES, Juarez. Teoria do Delito. São Paulo: Estúdio Editores, 2015, p. 11. 
ROSA, Alexandre Morais da; BISPO, Andrea Ferreira. Prostituição: o impasse entre o Legalismo Moral e o Princípio do Dano. Revista Eletrônica Direito e Política, Programa de Pós-Graduação Stricto Sensu em Ciência Jurídica da UNIVALI, Itajaí, v.12, n.3, $3^{\circ}$ quadrimestre de 2017. Disponível em: www.univali.br/direitoepolitica - ISSN 1980-7791

Assim, o Estado deve respeitar e permitir a vida autônoma enquanto essa não infringir direitos alheios, pois se mandados fundados em pretensões moralizadoras da vida privada se tornarem leis penais, ocorrerá uma subversão do fundamento da dignidade da pessoa humana.

Em segundo lugar, tem-se que somente devem ser protegidos pelo Direito Penal os bens jurídicos considerados indispensáveis à consecução dos objetivos nacionais, os quais representam o que uma sociedade entende como ideal de vida boa.

Em terceiro lugar, as normas penais devem estar vinculadas às exigências constitucionais orientadas pela proteção da pessoa humana, as quais estão arroladas no artigo 50, da CRFB, como direitos invioláveis e são: a vida, a liberdade, a igualdade, a propriedade e a segurança.

Desse modo, a eleição de bens jurídicos deve, necessariamente, estar atrelada a esses direitos reconhecidos como invioláveis, de onde se afirma que o objetivo da criminalização é, de um lado, resguardar a pessoa humana contra atos que violentem esses direitos e, de outro, resguardar a autonomia, impossibilitando a intervenção do Estado para a correção de condutas meramente inadequadas, exclusivamente autolesivas, moralmente reprováveis, que atinjam direitos não considerados invioláveis ou que, atingindo direitos invioláveis, podem ser evitadas com instrumentos diversos do Direito Penal.

Em síntese: o Direito Penal é um instrumento adequado apenas para a proteção de direitos invioláveis e ainda assim quando, e somente quando, outras formas de proteção a esses direitos não atingirem esse objetivo e, na medida em que está delimitado pelo princípio da dignidade humana, sua interferência na liberdade individual, quantitativa e qualificativamente, deve se restringir ao absolutamente necessário.

Com esses princípios determinantes, pode-se reconhecer que a conduta de sujeitos capazes, no gozo de sua autonomia, que elegem a prostituição, de forma imediata ou mediata, como seu trabalho, não ofende a qualquer direito inviolável descrito na Constituição, logo em um Estado Democrático de Direito, 
ROSA, Alexandre Morais da; BISPO, Andrea Ferreira. Prostituição: o impasse entre o Legalismo Moral e o Princípio do Dano. Revista Eletrônica Direito e Política, Programa de Pós-Graduação Stricto Sensu em Ciência Jurídica da UNIVALI, Itajaí, v.12, n.3, $3^{\circ}$ quadrimestre de 2017. Disponível em: www.univali.br/direitoepolitica - ISSN 1980-7791

tais condutas não poderão ser atingidas no processo de criminalização primária, uma vez que normas penais paternalistas são incompatíveis com o direito à liberdade individual.

De outro lado, se o bem jurídico supostamente tutelado pela norma penal é a dignidade sexual, ninguém que exerça qualquer profissão por livre disposição pode ser constrangido a adotar para si um conceito de dignidade que não Ihe diz respeito.

Por último, considerando que as prestações de serviços envolventes à sexualidade constituem atividades comuns e permitidas em outros contextos tais como casas de espetáculo, bares, motéis, agendamento de atendimento ao público e televenda, por exemplo -, a falta de regulamentação da profissão em razão do elemento normativo "prostituição" constitui tratamento desigual a uma categoria de trabalhadores, o que implica em criminalização indireta, dado que as profissionais do sexo ficam expostas às mais diversas modalidades de assédio moral, especialmente os protagonizados pelas agências de controle social e penal, tornando ainda mais precárias as condições materiais e sociais de uma atividade que, em razão da clandestinidade, já se encontra inserida em um reconhecido eixo produtor de desigualdade.

Dessa forma, a inexistência de regulamentação ratifica o estigma delinquencial e marginaliza uma atividade lícita, gerando a exclusão social de toda uma classe de trabalhadores, de onde se conclui que o reconhecimento oficial da profissão é indispensável para a salvaguarda de seus direitos fundamentais.

\section{CONSIDERAÇÕES FINAIS}

Ao consultarmos o passado, verificamos que a história da prostituição não é um capítulo a parte na forja social que instituiu as concepções de gênero e negou a participação das mulheres em sua estrutura jurídica-políticainstitucional.

O preconceito histórico-cultural contra as mulheres que exercem a prostituição foi construído no tear patriarcal, onde a subjugação do feminino 
ROSA, Alexandre Morais da; BISPO, Andrea Ferreira. Prostituição: o impasse entre o Legalismo Moral e o Princípio do Dano. Revista Eletrônica Direito e Política, Programa de Pós-Graduação Stricto Sensu em Ciência Jurídica da UNIVALI, Itajaí, v.12, n.3, $3^{\circ}$ quadrimestre de 2017. Disponível em: www.univali.br/direitoepolitica - ISSN 1980-7791

foi tecida com violência assustadoramente exacerbada contra aquelas que, dispensando o papel tutelar dos homens, ousavam decidir sobre a própria sexualidade.

Para reduzir a importância da autonomia quanto ao exercício da sexualidade, as prostitutas são alocadas à margem dos Direitos Humanos, já que a pauta conservadora-punitivista se serve do estigma de agente delinquencial que é imposto a elas para associar a prostituição à criminalidade.

Essa associação, longe de ser aleatória, tem se mostrado eficaz para excluir essa categoria profissional da esfera de proteção constitucional deferida aos demais trabalhadores.

Entretanto, em Estados Democráticos, para que seja possível interditar possibilidades interpretativas e descritivas do universo de práticas sociais e de relações econômicas, sexuais e afetivas por meio do Direito Penal é necessário mais que pretensões virtuosas ou a invocação de um senso de moralidade sexual que deveria comandar, uniformemente, o comportamento cotidiano.

Em ambientes nos quais se prima pela liberdade, a ideologia dominante, que nega o fundamento social de todo comportamento individual, deve ceder diante da garantia de que a intervenção do Estado na vida privada assuma e valorize os direitos humanos, a autonomia individual, a diversidade e a participação de todos na vida comunitária e nos processos decisórios.

Desse modo, se pretendemos afirmar que não há democracia sem liberdade, nem liberdade sem igualdade, e se tudo isso nos importa, é preciso admitir que o estigma que recai sobre a prostituta a coloca em situação de emergência e vulnerabilidade social.

Diante de pessoas que se afirmam plenamente contempladas com a profissão de prostituta, cabe ao Estado o ônus de indicar qual direito que a Constituição considera inviolável eles estão desrespeitando antes de proceder à criminalização 
ROSA, Alexandre Morais da; BISPO, Andrea Ferreira. Prostituição: o impasse entre o Legalismo Moral e o Princípio do Dano. Revista Eletrônica Direito e Política, Programa de Pós-Graduação Stricto Sensu em Ciência Jurídica da UNIVALI, Itajaí, v.12, n.3, $3^{\circ}$ quadrimestre de 2017. Disponível em: www.univali.br/direitoepolitica - ISSN 1980-7791

ou negar-lhes proteção jurídica.

Na medida em que não é possível apresentar essa justificativa, a criminalização de todos aqueles que trabalham de forma mediata na prostituição, e a omissão quanto à regulamentação da profissão constitui, de um lado, vício de inconstitucionalidade e, de outro, discriminação atentatória aos direitos à liberdade e à igualdade de tratamento perante a lei, situação incompatível com países comprometidos com a defesa dos Direitos Humanos.

\section{REFERÊNCIAS DAS FONTES CITADAS}

BARRETO, Maria de Lourdes Araújo. Todos calam, nós falamos. Comitê Latino Americano e do Caribe para a Defesa dos Direitos da Mulher (CLADEM). Mulheres: vigiadas e castigadas. São Paulo: Cladem-Brasil, 1995.

BOEHNER, Philotheus. GILSON, Etienne. História da filosofia cristã: desde as origens até Nicolau de Cusa. Trad. Raimundo Vier. 13. Ed. Petrópolis: Vozes, 2012.

BRASIL. Câmara dos Deputados. Comissão Parlamentar de Inquérito do Tráfico de Pessoas no Brasil. Audiência Pública realizada em 13 ago. 2013. Disponível em http://www2.camara.leg.br/atividadelegislativa/comissoes/comissoes-temporarias/parlamentar-de-inquerito/54alegislatura/cpi-trafico-de-pessoas-no-brasil/documentos/notastaquigraficas/nt130813-tpb. Acesso em 9 jun. 2017.

Código Civil (Lei no 3.071, de 10 de janeiro de 1916). Disponível em http://www.planalto.gov.br/ccivil_03/leis/L3071.htm. Acesso em 17 jun. 2017.

- Código Criminal do Império do Brasil (Lei Imperial de 16 de dezembro de 1830). Disponível em http://www.planalto.gov.br/ccivil_03/leis/lim/LIM-16-12-1830.htm. Acesso em: 17 jun. 2017.

Código Penal (Decreto n. 847, de 11 de outubro de 1890). Disponível em: $\quad$ http://legis.senado.gov.br/legislacao/ListaPublicacoes. action?id=66049. Acesso em 17 jun. 2017.

Código Penal (Decreto-Lei 2.848, de 07 de dezembro de 1940). Disponível em http://www.planalto.gov.br/ccivil_03/decretolei/Del2848compilado.htm. Acesso em: 17 jun. 2017.

Constituição Politica do Império do Brasil. Outorgada em 25 de março de $1824 . \quad$ Disponível em: http://www.planalto.gov.br/ccivil_03/constituicao/constituicao24.htm. Acesso em: 17 jun. 2017. 
ROSA, Alexandre Morais da; BISPO, Andrea Ferreira. Prostituição: o impasse entre o Legalismo Moral e o Princípio do Dano. Revista Eletrônica Direito e Política, Programa de Pós-Graduação Stricto Sensu em Ciência Jurídica da UNIVALI, Itajaí, v.12, n.3, $3^{\circ}$ quadrimestre de 2017. Disponível em: www.univali.br/direitoepolitica - ISSN 1980-7791

Constituição da República Federativa do Brasil. Promulgada em 05 de outubro de 1988. Publicada no Diário Oficial da União de 05.10.1988. Disponível em https://www.parlamento.pt/Parlamento/Documents/CRP-1822.pdf

Lei Mello Franco (Lei 2.992, de 25 de setembro de 1915). Disponível em Disponível em http://www2.camara.leg.br/legin/fed/lei/1910-1919/lei-299225-setembro-1915-774536-publicacaooriginal-138024-pl.html. Acesso em 17 jun. 2017.

Lei 12.015. Publicada em 07 de agosto de 2009. Disponível em http://www2.camara.leg.br/legin/fed/lei/2009/lei-12015-7-agosto-2009-590268exposicaodemotivos-149280-pl.html. Acesso em 17 jun. 2017.

CARMO, Paulo Sérgio do. Entre a Luxúria e o Pudor: a história do sexo no Brasil. São Paulo: Octávio, 2001.

ENGELS, Friedrich. A origem da família, da propriedade privada e do Estado. Trad. Leandro Konder. 9a ed. Rio de Janeiro: Civilização Brasileira, 1984.

FINNIS, John Mitchell. Lei Natural e Direitos Naturais. Trad. de Leila Mendes. São Leopoldo: Unisinos, 2007.

FOLHA DE BOA VISTA. PF deflagra operação em zona de prostituição da Capital e do Interior. Disponível em: http://www.folhabv.com.br/noticia/-PFdeflagra-operacao-em-zona-de-prostituicao-da-Capital-e-do-Interior/28056.

Acesso em 04 jul 2017.

FONSECA, Guido. A História da Prostituição em São Paulo. São Paulo: Editora Resenha Universitária, 1982.

FOUCAULT, Michel. História da Sexualidade 1, A Vontade de Saber. Trad. Maria Tereza da Costa Albuquerque e J. A. Guilhon Albuquerque. Rio de Janeiro/São Paulo: Paz \& Terra, 2015.

HOLTZ, Edson Leme. Noites Ilícitas: histórias e memórias da prostituição. Londrina: EDUEL, 2005.

KRAMER, Heinrich; SPRENGER, James. Malleus Maleficarum: O Martelo das Feiticeiras. Trad.: Paulo Froes. Rio de Janeiro: Best Bolso, 2015

KUSHNIR, Beatriz. Baile de Máscaras. Mulheres Judias e Prostituição. As Polacas e suas Associações de Ajuda Mútua. Rio de Janeiro, Imago, 1996.

LEITE, Gabriela. Filha, Mãe, avó e puta. Rio de Janeiro: Objetiva, 2009.

LINS, Regina Navarro. A cama na varanda: arejando nossas ideias a respeito de amor e sexo: novas tendências. Rio de Janeiro: BestSeller, 2007.

MENEZES, Lena Medeiro de. Estrangeiros e o Comércio do Prazer nas Ruas 
ROSA, Alexandre Morais da; BISPO, Andrea Ferreira. Prostituição: o impasse entre o Legalismo Moral e o Princípio do Dano. Revista Eletrônica Direito e Política, Programa de Pós-Graduação Stricto Sensu em Ciência Jurídica da UNIVALI, Itajaí, v.12, n.3, $3^{\circ}$ quadrimestre de 2017. Disponível em: www.univali.br/direitoepolitica - ISSN 1980-7791

do Rio - 1890 à 1930. Rio de Janeiro: Arquivo Nacional, 1992.

MILL, John Stuart. Sobre a Liberdade. Trad. Denise Bottmann. Porto Alegre: L\&PM, 2016.

NÓBREGA, Manoel da. Cartas do Brasil 1549-1560. Rio de Janeiro: Publicações da Academia Brasileira, 1931.

PADOVANI, Tulio. Il testo único sull'immigrazione e le strategie di contrasto allo sfruttamento sessuale: I'innovazione legislativa del programma di protezione sociale e l'impatto prodotto nel contesto sociale. In: Stop tratta: Atti del Convegno Internazionale. Bologna, 23/24 de maggio de 2002. Martinsicuro: On The Road Edizioni, 2002.

RAGO, Margareth. Do cabaré ao lar: a utopia da cidade disciplinar: Brasil: 1890 -1930. Rio de Janeiro: Paz e Terra, 1985.

Os prazeres da noite. Prostituição e Códigos da Sexualidade Feminina em São Paulo (1890 -1930). São Paulo: Paz e Terra, 2008.

RIO DE JANEIRO. Assembleia Legislativa. Comissão de Defesa dos Direitos Humanos e Cidadania. Comissão de Defesa dos Direitos da Mulher. Audiência Pública realizada em 06 abr. 2014. Disponível em: http://alerjln1.alerj.rj.gov.br/compcom.nsf/e36c0566701326d503256810007413 ca/e2d2376350a1e9f283257d1c00556eba?OpenDocument. Pesquisa realizada em 17 jun. 2017.

ROSSIAUD, Jacques. A Prostituição na Idade Média. Trad. Cláudia Schilling. Rio de Janeiro: Paz e Terra, 1991.

SIMÕES, Soraya Silveira. Vila Mimosa: etnografia da cidade cenográfica da prostituição carioca. Niterói: EdUFF, 2010.

SOIHET, Rachel. Condição Feminina e Formas de Violência: mulheres pobres e ordem urbana 1890-1920. Rio de Janeiro: Forense Universitária, 1989.

SOUZA, Jessé. Ralé Brasileira: quem é e como Vive. Belo Horizonte: Editora UFMG, 2009.

TAVARES, Juarez. Teoria do Delito. São Paulo: Estúdio Editores, 2015.

WELZEL, Hans. Derecho Penal Alemán: Parte Geral. $4^{a}$ ed. Santiago do Chile: Jurídica de Chile, 1997.

Submetido em: dezembro de 2017

Aprovado em: dezembro de 2017 